\title{
PENENTUAN DOSIS MINIMUM EKSTRAK ETANOL HERBA KROKOT (Portulaca oleracea L.) TERHADAP PENURUNAN KADAR TRIGLISERIDA PADA TIKUS OBESITAS
}

\author{
Irma Santi, Rizqi Nur Azizah, Mu'ammar \\ Fakultas Farmasi Universitas Muslim Indonesia, Makassar \\ Email Irma.santi@umi.ac.id
}

\begin{abstract}
Common purslane (Portulace Oleracea L.) has a compound of omega-3, flavonoid and ascorbic acid with the activity in decreasing triglyceride levels. This study aimed to determine the minimum dose of ethanol extract of common purslane against the decrease of triglyceride levels of obese mice. It used 18 rats fed highcalorie diet (HCD) for 30 days. The obese rats were devided into 6 groups consisting of group I of negative controls (Na.CMC), group II of positive control (gemfibrozil(囚), group III,IV, V, VI provided the ethanol extract of common purslane (EECP) with 25 $\mathrm{mg} / \mathrm{kgBW}, 50 \mathrm{mg} / \mathrm{kgBW}, 75 \mathrm{mg} / \mathrm{kgBW}, 100 \mathrm{mg} / \mathrm{kgBW}$. Afterwards, 14 days of therapy were given and still fed a high-calorie (HCD). The measurement of triglyceride levels is performed before induction (early). After induction, and after therapy. The data of the study were analized by percentage decrease of each test group. The result show that the EECP groups of $75 \mathrm{mg} / \mathrm{kgBW}$ was the minimum dose in lowering triglyceride levels with a decrease of $16,49 \%$.
\end{abstract}

Key words: Minimum Dose, Triglycerides, Portulaca Oleracea

\section{PENDAHULUAN}

Penyakit obesitas dinyatakan oleh WHO sebagai masalah kesehatan kronis terbesar pada orang dewasa dan telah menjadi masalah di seluruh dunia. Obesitas berdampak pada kira-kira 300 juta orang didunia. 1,2Data Riskesdas 2007 menunjukkan peningkatan prevalensi obesitas dalam beberapa tahun berdasarkan IMT pada kelompok umur $\geq 18$ tahun sebesar $10,3 \%$ pada tahun 2007,
11,7\% pada tahun 2010 dan 13,2\% pada tahun $2013 .^{3}$

Obesitas merupakan deposit lemak yang terjadi di dinding perut dan intraabdominal (lapisan ekstraperitoneal, omentum dan mesenterium) dan berat badan seseorang $120 \%$ lebih besar dari yang disarankan untuk tinggi, usia dan jenis kelamin mereka (Indeks massa tubuh). ${ }^{4}$ Pada penderita obesitas kadar trigliserida dalam darah lebih 
Penentuan dosis minimum ekstrak etanol herba krokot (Portulaca oleracea L.) terhadap penurunan kadar trigliserida pada tikus obesitas

tinggi dibandingkan orang yang tidak obesitas. ${ }^{5}$ Kadar trigliserida yang tinggi dikaitkan dengan peningkatan resiko penyakit vaskular. ${ }^{6}$

Penangulangan penyakit obesitas adalah dengan mengurangi jumlah kalori masuk, latihan fisik serta penggunaan obat-obat sintetik seperti derivat amfetamin dan SSRI (Selective serotonin reuptake inhibitor). Akan tetapi, efek samping obat sintetik yang ditimbulkan jika penggunaan dalam jangka panjang menjadi salah satu pertimbangan masyarakat beralih pada penggunaan obat tradisional. ${ }^{7}$

Dalam penelitiannya El-Newary menyatakan bahwa batang tumbuhan krokot (Portulaca olarecea L.) memiliki kandungan senyawa omega-3, flavanoid dan asam askorbat yang berkhasiat sebagai hipolipidemik untuk menurunkan kadar trigliserida. 8 Flavonoid dapat menurunkan TC, LDL$C$ dan VLDL-C namun meningkatkan HDL-C. ${ }^{9}$ Asam lemak omega-3 akan menekan sintesis trigliserida dalam hati, dengan sendirinya menekan VLDL dalam plasma dan mempengaruhi proses lipolisis pada jaringan lemak, sehingga trigliserida tidak terbentuk melalui reaksi asam lemak bebas dengan gliserol.$^{10}$

Penelitian sebelumnya yang telah dilakukan terhadap tumbuhan krokot (Portulaca oleracea L.) oleh Ashtiyani,didapatkan bahwa dosis terendah (200 mg/kgBB) dari variasi dosis ekstrak $200 \mathrm{mg} / \mathrm{kgBB}, 400$ $\mathrm{mg} / \mathrm{kgBB}, 800 \mathrm{mg} / \mathrm{kgBB} .{ }^{11}$ dan hasil yang sama didapatkan oleh penelitian yang juga dilakukan oleh azizah bahwa dosis terendah (100 mg/kgBB) dari variasi dosis ekstrak 100 $\mathrm{mg} / \mathrm{kgBB}, \quad 200 \mathrm{mg} / \mathrm{kgBB}, \quad 300$ $\mathrm{mg} / \mathrm{kgBB} .{ }^{12}$ yang paling efektif sebagai penurun kadar trigliserida pada tikus hiperlipidemia.

Pada kedua penelitian tersebut melaporkan bahwa ekstrak etanol herba krokot (Portulaca oleracea L.) dengan dosis minimum adalah yang paling baik dalam menurunkan kadar trigliserida dibandingkan dengan dosis maksimum. Namun, belum diketahui jelas batas dosis minimum dari ekstrak herba krokot (Portulaca oleracea L.) yang dapat menurunkan kadar trigliserida yang paling baik dalam menurunkan kadar trigliserida.

Penelitian ini merupakan penelitian lanjutan yang bersifat ekploratif. Parameter yang diamati adalah penurunan kadar trigliserida dalam darah sehingga berdasarkan dari penjelasan diatas maka dilakukan penelitian ini untuk menguji dosis minimum dari ekstrak etanol herba krokot (Portulaca olaracea L.) 
Penentuan dosis minimum ekstrak etanol herba krokot (Portulaca oleracea L.) terhadap penurunan kadar trigliserida pada tikus obesitas

terhadap penurunan kadar trigliserida pada tikus obesitas.

\section{METODE KERJA}

\section{Alat dan Bahan}

Alat-alat yang digunakan yaitu seperangkat alat maserasi, alat-alat gelas, Human Analyzer (Microlab 300), mikropipet (original eppendorf), sentrifuge. Bahan-bahan yang digunakan yaitu etanol $96 \%$, diet tinggi kalori, herba krokot (Portulaca $\begin{array}{lll}\text { oleracea } & \text { L.), } & \text { natrium }\end{array}$ karboksimetilselulosa (Na. CMC), reagen pengujian trigliserida (Triglyserides Mono SL New), dan Gemfibrozil $^{\circledR}$,

\section{Prosedur Kerja}

Pembuatan ekstrak etanol herba krokot (Portulaca oleracea L.)

Serbuk simplisia herba krokot (Portulaca oleracea L.) ditimbang sebanyak $500 \mathrm{~g}$, lalu dimasukkan ke dalam wadah maserasi. Setelah itu, wadah diisi dengan etanol hingga serbuk simplisia terendam. Simplisia direndam selama 6 jam pertama sambil diaduk sekali-kali, kemudiam didiamkan selama 18 jam dibiarkan pada suhu kamar dan terlindungi dari sinar matahari. Dipisahkan maserat dari residu dengan cara filtrasi atau penyaringan. Maserasi dilakukan selama 2 kali dengan jenis dan jumlah pelarut yang sama hingga diperoleh maserat terakhir yang jernih. Hasil penyarian yang diperoleh dipekatkan dengan menggunakan rotavapor hingga diperoleh ekstrak etanol kental $^{13}$

Pembuatan suspensi Natrium Karboksimetilselulosa (Na.CMC) 1\% b/v

Sebanyak 1 g Na.CMC ditimbang, lalu dimasukkan sedikit demi sedikit ke dalam $50 \mathrm{~mL}$ aquades yang telah dipanaskan (suhu $70^{\circ} \mathrm{C}$ ), sambil diaduk menggunakan pengaduk dan terbentuk larutan koloidal yang homogen. Setelah itu dicukupkan hingga volumenya $100 \mathrm{~mL}$ dengan aquades. ${ }^{14}$

\section{Pembuatan pakan diet tinggi kalori (DTKL)}

Komposisi dari pakan diet tinggi kalori untuk tiap $1 \mathrm{~kg}$ pakan yaitu tepung beras $300 \mathrm{~g} / \mathrm{kg}$, tepung jagung $200 \mathrm{~g} / \mathrm{kg}$, tepung ikan $100 \mathrm{~g} / \mathrm{kg}$, tepung kacang hijau $100 \mathrm{~g} / \mathrm{kg}$, tepung gandung $100 \mathrm{~g} / \mathrm{kg}$ dan lemak sapi 200 $\mathrm{g} / \mathrm{kg}$. kemudian, semua bahan dicampur dan dibuat adonan. Adonan dibentuk kecil-kecil kemudian dimasukkan kedalam oven. Pemberian pakan diet tinggi kalori diberikan sebagai pengganti pakan standar. ${ }^{15}$

\section{Pembuatan suspensi Gemfibrozil ${ }^{\circledR}$}

Tablet Gemfibrozil $300 \mathrm{mg}$ ditimbang sebanyak 20 tablet, dihitung 
Penentuan dosis minimum ekstrak etanol herba krokot (Portulaca oleracea L.) terhadap penurunan kadar trigliserida pada tikus obesitas

berat rata-ratanya. Setelah itu, tablet digerus dalam lumpang, kemudian ditimbang yang setara dengan 30,83 $\mathrm{mg} / 10 \mathrm{~mL}$, lalu disuspensikan dengan Na. CMC 1\% b/v hingga $10 \mathrm{~mL} .{ }^{16}$

Pembuatan suspensi ekstrak etanol herba krokot (Portulaca oleracea L.)

Suspensi ekstrak etanol herba krokot (Portulaca oleracea L.) dosis 25 $\mathrm{mg} / \mathrm{kgBB}, 50 \mathrm{mg} / \mathrm{kgBB}, 75 \mathrm{mg} / \mathrm{kgBB}$, dan $100 \mathrm{mg} / \mathrm{kgBB}$ dibuat dengan menimbang masing-masing ekstrak sebanyak $25 \mathrm{mg}, 50 \mathrm{mg}, 75 \mathrm{mg}$ dan 100 mg, kemudian masing-masing ekstrak disuspensikan dengan $10 \mathrm{~mL}$ Na.CMC $1 \%$ b/v. ${ }^{16}$

\section{Penyiapan Hewan Uji}

Hewan uji yang digunakan adalah tikus (Rattus norvegicus) jantan yang sehat dengan bobot badan 100200 g sebanyak 18 ekor, yang dibagi dalam 6 kelompok perlakuan, masingmasing kelompok terdiri dari 3 ekor hewan uji. Hewan uji diadaptasikan selama 2 minggu sebelum perlakuan. ${ }^{11}$

\section{Perlakuan Hewan Uji}

Hewan uji tikus dipuasakan selama \pm 8 jam. Setelah itu, dilakukan pengambilan darah untuk pengukuran kadar trigliserida tikus (kadar trigliserida awal). Semua kelompok diberi pakan diet tinggi kalori (DTKL) selama 30 hari lalu dilakukan pengukuran kadar trigliserida tikus (kadar trigliserda induksi). Kemudian kelompok I kontrol negatif diberikan suspensi Na.CMC 1\% b/v, kelompok II kontrol positif diberikan suspensi Gemfibrozil $^{\circledR} \quad 30,83 \mathrm{mg} / 10 \mathrm{~mL}$, kelompok III, IV, V dan VI diberikan ekstrak etanol herba krokot (Portulaca oleracea L.) dosis berturut-turut 25 $\mathrm{mg} / \mathrm{kgBB}$, $50 \mathrm{mg} / \mathrm{kgBB}, 75 \mathrm{mg} / \mathrm{kgBB}$, dan $100 \mathrm{mg} / \mathrm{kgBB}$. Pemberian dilakukan secara oral selama 14 hari dan tetap diberikan pakan diet tinggi kalori (DTKL). Pada hari ke 15 dilakukan pengukuran kadar trigliserida terapi tikus (kadar trigliserida akhir). ${ }^{11}$

Pengambilan sampel darah hewan uji

Sampel darah diambil lewat vena lateralis pada ekor tikus. Darah ditampung pada tabung Eppendorf sebanyak $1 \mathrm{~mL}$, kemudian disentrifugasi selama 10 menit dengan kecepatan $3.000 \mathrm{rpm}$, lalu diambil serumnya (lapisan bening). ${ }^{16}$

\section{Pengukuran kadar trigliserida hewan uji}

Serum darah sebanyak $3 \mu \mathrm{l}$ ditambahkan $300 \mu \mathrm{l}$ reagen trigliserida, kemudian divortex kemudian dimasukkan dalam Human Analyzer untuk diukur kadar trigliseridanya. ${ }^{16}$ 
Penentuan dosis minimum ekstrak etanol herba krokot (Portulaca oleracea L.) terhadap penurunan kadar trigliserida pada tikus obesitas

HASIL PENELITIAN

Hasil rata-rata pengukuran terapi pada tikus obesitas dapat dilihat pada tabel 1 dibawah ini :

kadar trigliserida awal, induksi dan

Tabel 1. Rata-rata pengukuran kadar trigliserida awal, induksi dan terapi pada tikus obesitas.

\begin{tabular}{lcccc}
\hline \multicolumn{1}{c}{ Kelompok } & Awal \pm SD & Induksi \pm SD & Terapi \pm SD & $\%$ penurunan \\
\hline Kontrol negative & $79,50 \pm 0,70$ & $154,50 \pm 4,94$ & $196,50 \pm 2,12$ & $-27,22$ \\
Kontrol positif & $79,20 \pm 4,94$ & $185,00 \pm 1,41$ & $58,50 \pm 3,53$ & 68,36 \\
EEHK 25mg/KgBB & $86,00 \pm 5,65$ & $157,00 \pm 9,19$ & $178,00 \pm 2,82$ & $-13,15$ \\
EEHK 50mg/KgBB & $83,00 \pm 2,82$ & $151,50 \pm 9,12$ & $159,00 \pm 5,65$ & $-5,02$ \\
EEHK 75mg/KgBB & $86,50 \pm 4,94$ & $174,50 \pm 19,9$ & $145,50 \pm 12,02$ & 16,49 \\
EEHK 100mg/KgBB & $81,00 \pm 8,48$ & $185,00 \pm 1,41$ & $118,00 \pm 0,70$ & 36,22 \\
\hline
\end{tabular}

\section{PEMBAHASAN}

Trigliserida merupakan komponen lemak utama dalam asupan makanan, terdapat sekitar $98 \%$ dari total lemak dan $2 \%$ sisanya terdiri atas fosfolipid dan kolesterol (bebas dan ester). Trigliserida dapat disimpan dalam jumlah berlimpah untuk memasok kebutuhan energi tubuh selama berbulan-bulan, seperti dalam kasus orang obesitas. Trigliserida disimpan dalam jaringan adiposa, otot rangka, hati, paru-paru, dan usus untuk menyediakan energi untuk proses metabolism. ${ }^{17}$

Kadar trigliserida yang tinggi memiliki hubungan sebab akibat langsung dengan obesitas. Hormon leptin, yang fungsinya memberitahu otak agar bisa berhenti makan saat kenyang, dapat dihambat oleh trigliserida untuk mencapai otak sehingga tubuh akan terus makan dan terjadilah obesitas. ${ }^{18}$ Penumpukan lemak berlebihan yang terjadi pada penderita obesitas mengakibatkan meningkatnya jumlah asam lemak bebas Free Fatty Acid (FFA) yang dihidrolisis oleh lipoprotein lipase (LPL). Peningkatan ini memicu produksi oksidan yang berefek negatif terhadap retikulum endoplasma dan mitokondria. Free Fatty Acid (FFA) yang dilepaskan karena adanya penimbunan lemak yang berlebihan juga menghambat terjadinya lipogenesis sehingga menghambat klirens serum triasilgliserol sehingga mengakibatkan peningkatan kadar trigliserida darah (hipertrigliseridemia). ${ }^{21}$

Penelitian ini menggunakan 18 ekor tikus yang diberi pakan diet tinggi kalori selama 30 hari. Setelah itu hewan coba obesitas dibagi menjadi 6 kelompok yang terdiri dari kelompok I 
Penentuan dosis minimum ekstrak etanol herba krokot (Portulaca oleracea L.) terhadap penurunan kadar trigliserida pada tikus obesitas

negatif (Na.CMC), kelompok II positif

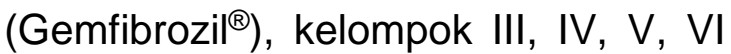
yang diberikan ekstrak etanol herba krokot (EEHK) dengan dosis berturut $25 \mathrm{mg} / \mathrm{kgBB}, \quad 50 \mathrm{mg} / \mathrm{kgBB}, \quad 75$ $\mathrm{mg} / \mathrm{kgBB}$ dan $100 \mathrm{mg} / \mathrm{kgBB}$. Setelah itu diberikan terapi selama 14 hari dan tetap diberikan pakan diet tinggi kalori (DTKL). Pengukuran kadar trigliserida dilakukan sebelum induksi (awal), setelah induksi, dan setelah terapi. Data hasil penelitian dianalisis berdasarkan persen penurunan tiap kelompok uji.

Penelitian ini dimulai dengan pemberian pakan tinggi karbohidrat yang tinggi dengan komposisi tepung beras, tepung jagung, tepung ikan, tepung kacang hijau, tepung gandung dan lemak sapi.${ }^{15}$ Komposisi tersebut dapat meningkatkan kadar fruktose 2,6 bifosfat yang mengaktifkan fosfruktokinase-1 sehingga merangsang terjadinya peningkatan reaksi glikolisis, reaksi glikolisis ini meningkatkan kadar asam lemak yang berikatan dengan gliserol membentuk trigliserida yang telah diadaptasi selama 2 minggu sebelumnya. Pemberian pakan dilakukan selama 30 hari untuk mendapatkan kadar trigliserida tikus melebihi kadar normal trigliserida yaitu 26-145 $\mathrm{mg} / \mathrm{dL}$. Setelah itu dilakukan terapi selama 14 hari dan tetap diberikan pakan diet tinggi kalori (DTKL) dan diukur kadar trigliserida setelah terapi pada hari ke15.

Pada tabel 1 menunjukkan bahwa terjadi peningkatan kadar trigliserida pada semua kelompok induksi yang disebabkan oleh pemberian pakan diet tinggi kalori (DTKL) selamar 30 hari yang ditunjukkan dengan kadar trigliserida semua kelompok diatas $145 \mathrm{mg} / \mathrm{dl}$. Setelah 14 hari terapi, pada kelompok kontrol negatif tidak menunjukkan penurunan kadar trigliserida yang artinya Na.CMC tidak memiliki efek untuk menurunkan trigliserida. Sedangkan pada kontrol positif yang diberikan gemfibrozil menunjukkan penurunan kadar trigliserida sebesar $68,36 \%$. Dilain pihak, pada dosis ekstrak etanol herba krokot (Portulaca oleracea L.) (EEHK) $75 \mathrm{mg} / \mathrm{kgBB}$ dan $100 \mathrm{mg} / \mathrm{kgBB}$ menunjukkan penurunan kadar trigliserida $16,49 \%$ dan $36,22 \%$ dibanding dosis ekstrak etanol herba krokot (Portulaca oleracea L.) 25 $\mathrm{mg} / \mathrm{kgBB}$ dan $50 \mathrm{mg} / \mathrm{kgBB}$ yang tidak menunjukan penurunan kadar trigliserida.

Penurunan kadar trigliserida pada kelompok ekstrak $75 \mathrm{mg} / \mathrm{kgBB}$ dan $100 \mathrm{mg} / \mathrm{kgBB}$ diduga karena ekstrak etanol herba krokot (Portulaca 
Penentuan dosis minimum ekstrak etanol herba krokot (Portulaca oleracea L.) terhadap penurunan kadar trigliserida pada tikus obesitas

oleracea L.) sebagai penurun kadar trigliserida yang mengandung omega3, flavanoid dan asam askorbat yang berkhasiat sebagai hipolipidemik untuk menurunkan kadar trigliserida. ${ }^{8,11}$ Penurunan kadar trigliserida pada kelompok positif gemfibrozil karena gemfibrozil merupakan derivat asam fibrat generasi pertama turunan klofibrat. Obat ini bekerja dengan cara meningkatkan lipolisis lipoprotein trigliserida melalui lipoprotein lipase yang berikatan dengan reseptor alfa peroxisome proliferator-activated reseptor (PPAR- $\alpha$ ) pada hepatosit. Gemfibrozil menurunkan kolesterol total sebesar $10 \%$, kolesterol LDL sebesar $11 \%$, meningkatkan kadar kolesterol HDL sebesar $11 \%$ dan menurunkan trigliserida sebesar $35 \% .^{20}$

Dari penelitian ini didapatkan bahwa dosis minimum ekstrak etanol herba krokot (Portulaca oleracea L.) dalam menurunkan kadar trigliserida pada tikus obesitas adalah dosis 75 $\mathrm{mg} / \mathrm{kgBB}$.

\section{KESIMPULAN}

Berdasarkan penelitian yang dilakukan dapat disimpulkan bahwa dosis minimum ekstrak etanol herba krokot (Portulaca oleracea L.) terhadap penurunan kadar trigliserida tikus obesitas adalah dosis 75 $\mathrm{mg} / \mathrm{kgBB}$.

\section{DAFTAR PUSTAKA}

1. WHO. Global Status Report on Noncommunicable Diseases'. Switzeland, 2014.

2. Sun $Y$, Chen J. Intestinal Electric Stimulation Decreases Fat Absorption in Rats: Therapeutic Potential For Obesity. Absorption of nutria Recived for review September 25, 2003. Obesity research. 2004:12(8).

3. Badan Penelitian dan Pengembangan Kesehatan. Pokokpokok hasil Riskesdas 2013. Jakarta, 2013.

4. Grace, Pierce A. Neil R, Borley. Surgery at a Glance Ed.2. USA: A Blackwell Publishing Company, 2002

5. Bull, Eleanor \& Jonathan Morrell, Kolesterol. Jakarta: Erlangga, 2007.

6. Ginsberg L. Lecture Notes : Neurology. Jakarta: Erlangga, 2008.

7. Lipton Institute of Tea. Caffeine A Harmful or Beneficial Compounds ?'.http://www.lipton.com/en_en/Lipt on_Institute_of)Tea1,10.aspx\#Our $\%$ 20publicati ons-1,123, 20 Februari 2009.

8. El-Newary SA. The Hipolipidemic effect of Portulaca oleraceae L. stem on hyperlipidemic Wister Albino Rats. Analysis of Agricultural Science. 2016;61(1):111-112.

9. Koshy AS, Anila L, Vijayalakshmi NR. Flavonoids from Garcinia cambogia lower lipid level in 
Penentuan dosis minimum ekstrak etanol herba krokot (Portulaca oleracea L.) terhadap penurunan kadar trigliserida pada tikus obesitas

hypercholesterolemic rats. Food Chem. 2001;72:289-294.

10. Duthie IF \& Barlow SM. Dietary lipid exemplified by fish oils and their n-3 facid acid. Food Sci Technol. 1992;6:20.

11. Ashtiyani, Zarei A, Taheri S, Rasekh F, Ramazan M. The Effects of Portulaca Oleraceae Alcoholic Extract on Induced Hypercholestroleomia in Rats. Journal of Research in Medical Sciences.2012;15(6):36.

12. Azizah RN, Putra B. Tobis R. Aktivitas hipolipidemik dari ekstrak etanol herba krokot (Portulaca oleracea L.) pada tikus obesitsas dengan parameter trigliserida', Jurnal As-Syifaa. 2017;09(01):6678.

13. Kementerian Kesehatan RI. Suplemen farmakope herbal Indonesia. Jakarta, 2010.

14. Santi I, Putra B, Wahyuni S. uji efek ekstrak etanol daun cincau hijau (Cyclea barbata miers) sebagai antiinflamasi pada tikus putih yang diinduksi karagen. Jurnal As-Syifaa. 2017;09(01):5866.

15. Abuzaid AS, Sukandar EY, Kurniati NF, Adnyana, IK. Preventive Effect on Obesity of Mangosteen (Garcinia mangostana L.) Pericarp Ethanolic Extract by Reduction of Fatty Acid Synthase Level in Monosodium Glutamate and HighCalorie Diet-Induced Male Wistar Rats. Asian Journal of
Pharmaceutical and Clinical Research. 2016;9:257-260.

16. Rahmawati. Uji Efektivitas Kombinasi Ekstrak Etanol Daun Jambu Biji (Psidium guajava Linn) dengan Daun Salam (Syzygium polyanthum) terhadap Penurunan Kadar Trigliserida pada Tikus Hiperlipidemia (Skripsi). Makassar: Farmasi, Fakultas Farmasi, Universitas Muslim Indonesia, 2016.

17.Dashty MA. Quick Look at Biochemistry : Lipid Metabolism. Department of Cell Biology, University Medical Center Groningen, University of Groningen, The Netherlands. J Diabetes \& Metabolism.2014:15.

18. Stankus T. Lowering Triglycerides: Dieting, Exercise, Niacin, Statins, Fibrates, Nuts \& Fish. http://sladivisions.typepad.com/dbio 2009/05/ lowering triglyceridesdietingexercise-niacinstatin -fibrates-nuts-fish.html.(7 Maret 2010).

19. Syarief, Fatimah. Efek Suplementasi Serat Chitosan dengan Omega-3 dalam Minyak Ikan Terhadap Trigliserida Plasma dan Kolesterol Total pada Pekerja Obes. Jurnal Kedokteran Indonesia. 2011;2(1):23-29.

20. Mahley RW, Bersot TP. Terapi Obat untuk Hiperkolesterolemia dan Dislipidemia, dalam: Goodman Gilman, A. (Ed.). Bandung: Tim Alih Bahasa Sekolah Farmasi ITB (Penerjemah), Goodman \& Gilman Dasar Farmakologi Terapi, Jakarta, 2003.pp: 943-973. 